\title{
GENETIC CONTROL FOR MATURITY AND YIELD TRAITS IN MAIZE
}

\author{
Adilson Ricken Schuelter ${ }^{1}$, Jonatas Marcolin ${ }^{2}$, Talles de Oliveira Santos ${ }^{3}$, \\ Diogo Dembocurski ${ }^{1}$, Elaine Cristina Disner ${ }^{1}$, Ivan Schuster ${ }^{4}$
}

\begin{abstract}
1) Faculdade Educacional de Medianeira (UDC Medianeira), Medianeira, PR, 85884-000;
2) Corteva Agriscience, Toledo, PR, 85970-000;

3) Laboratório de Melhoramento Genético Vegetal, Universidade Estadual do Norte Fluminense Darcy Ribeiro (UENF), Campos dos Goytacazes, RJ, 28013-602;
\end{abstract}

4) Longping High-Tech, Cravinhos, SP, 14140-000.

Corresponding author: Adilson Ricken Schuelter (adilson schuelter@yahoo.com.br)

\begin{abstract}
An understanding of the genetic control of a trait is very important for the efficient implementation of a breeding program. This study aimed to obtain information about the genetic control of male and female flowering and crop humidity, related to the maturation and grain yield and mass attributes of a thousand seeds, through diallel analysis. Thirteen elite lines of the Coodetec breeding program were selected and seventy-eight hybrids were synthesized as a half table diallel. The hybrids and parentals were evaluated in Palotina, Mariluz and São Pedro do Iguaçu, in a 10x10 square lattice experimental design, with three replications. Male and female flowering, crop humidity, thousand seed weight and grain yield were evaluated. Analyses of individual and joint variance and of diallel analysis were performed using the Hayman methodology. Analyzes of individual variance reveal variability in all the traits studied. The genetic model was observed in at least two tests of significance of the dominant additive model. The genetic information showed that dominant alleles are found more frequently in the genitors, except for yield, which is predominantly recessive. Dominant gene effects are predominant in the control of the variables studied with an overdominance interaction between the alleles. The CD069 line shows a higher number of dominant genes for maturation and the CD038 line had a higher number of dominant genes for yield. It is possible to have greater selection gains for male and female flowering and one thousand seed weight in the Palotina environment. For crop humidity greater gains are possible in the Mariluz and Palotina environments.
\end{abstract}

Keywords: Genetic components, overdominance, diallel of Hayman. 


\section{Introduction}

Corn was traditionally a typical springsummer crop, sown between August and November (Fornasieri Filho, 2007). In Paraná, in the 70's, the cultivation of corn second season began sown between January and March and, currently, this activity represents more than $80 \%$ of corn cultivated in the state (SEAB/DERAL, 2017). The consolidation of the off-season in Paraná occurred by the great technological advance, especially by the use of simple hybrids, early cycles and adapted to the autumn-winter climatic conditions (Fornasieri Filho, 2007).

In order to meet the market demand for early, productive hybrids adapted to the growing conditions, knowledge of the genetic control of such traits is fundamental for conducting a breeding program, assisting in the selection of more efficient selection methods (Cruz et al., 2012). To this end, the use of diallel crosses is efficient for generating information on parents for population synthesis, identification of efficient selection methods and knowledge of the genetic bases that control such traits (Cruz et al., 2012; Makumbi et al., 2018).

For the study of genetic control, we highlight the methodology proposed by Hayman (1954), which is based on the knowledge of the environmental and genetic nature of means, variances and covariance, obtained from a diallel table and, in addition to genetic control, provides information on parent genetic values, selection limits, ratio of dominant to recessive genes and coefficient of genotypic determination and number of genes or gene blocks that control the variable under study (Cruz et al., 2012; Rohman et al., 2019). However, for the use of this methodology, some premises must be met, such as diploid segregation, use of homozygous parents, absence of maternal effect, absence of multiple allelism, independent distribution of genes and absence of epistasis, which may be obstacles to the use of this method (Schuelter et al., 2010; Cruz et al., 2012).

For corn cultivation, some authors used this methodology to generate information about several quantitative characters of interest, such as Lopes et al. (1995) who studied inheritance of the number of days for flowering and concluded that it is controlled by at least three genes or gene blocks and by additive and dominance effects. Saleem et al.
(2002) studying the number of days for male and female flowering, number of rows of grains per cob, number of grains per row and mass of one hundred seeds, concluded that over-dominance is the gene action that controls these traits. Wattoo et al. (2009) studied days for male and female flowering, number of grain rows per bob, plant height, number of cobs per plant, number of grains per row, mass of one hundred seeds, yield and percentage of protein and oil in seeds and detected overdominance and nonadditive gene action for the yield components. Sher et al. (2012) studied maturity and flowering and observed dominance action and epistatic interaction in the control of these characters.

Although traits related to maturity and yield in maize are of great importance and researchers devote their attention to it, the studies present divergent results, both in terms of gene effects, heritability and number of genes involved (Lima et al., 2008). Thus, this study aimed to obtain information on the genetic control of the attributes male flowering, female flowering and crop humidity, related to maturity and the attributes grain yield and mass of one thousand seeds, through diallel analysis.

\section{Materials and methods}

\section{Genetic material and growing conditions}

Thirteen elite lines from the Coodetec (Cooperativa Central de Pesquisa Agrícola) Southern Corn Breeding Program with late-to-late cycle selected from Friske's (2015) assessment were employed to obtain $F_{1}$ populations following a scheme of diallel crossing half table. Seeds were obtained by hand crossing block sown in summer 2014/2015 at Coodetec experimental farm in Palotina/PR.

The experiments were carried out in the second season of 2015 in the municipalities of Palotina, São Pedro do Iguaçu and Mariluz, Paraná, respecting the agroclimatic zoning of the Ministério da Agricultura, Pecuária e Abastecimento for each site being sowed on February $27^{\text {th }}$, February $17^{\text {th }}$ and February $22^{\text {nd }}$ of 2015 , respectively.

The experiments counted on the 13 parent lines, the $78 \mathrm{~F}_{1}$ hybrids and 9 commercial hybrids, totaling 100 treatments. The experimental design used was the 10x10 lattice with three replications. 
The experimental unit was two lines with 5 meters in length and 0.76 meters of line spacing. Sowing was mechanized and between 25 and 30 days after plant emergence thinning was performed, establishing an average population of 65,000 plants ha ${ }^{-1}$.

\section{Evaluated traits}

To determine the number of days for male (MF) and female (FF) flowering, visual evaluations were made of all plots of each trial with two-day periodicity between evaluations, always at the same time of day and same evaluator, considering for FM and $\mathrm{FF}$ the number of days between planting and when $50 \%+$ one of the plants had pollen emission and style-stigmas exposed.

To determine the mass of one thousand seeds (MTS), five ears of each plot were randomly collected, threshed and taken to the dryer until reaching $13 \%$ of humidity. The MMS value of each plot was calculated through the average weight of six samples of 100 seeds.

The percentage of humidity in the grain mass (HUM) was determined at the time of harvest through the plot harvester. The grain yield (GY) was calculated from the data of mass and humidity of each plot provided by the harvester by adding the grain weight of the 5 ears collected to determine the MTS and adjusted to $13 \%$ of humidity and expressed in $\mathrm{kg} \mathrm{ha}^{-1}$.

Harvesting was mechanized and performed in the total area of each plot. To determine the mass of one thousand seeds (MTS), five ears of each plot were randomly collected, threshed and taken to the dryer until they reached $13 \%$ humidity. The MTS value of each plot was calculated through the average weight of six samples of 100 seeds.

\section{Genetic-statistical analysis}

For all statistical analysis, the 13 progenitor lines and 78 diallel hybrids were considered. The efficiency of the lattice design was estimated for all evaluated characters, being for all of them below the $120 \%$ efficiency limit that would justify the work in this methodology, allowing to work with the randomized block statistical model (Moraes et al., 1988; Gomes and Garcia, 1991).

After defining the statistical model, individual variance analyzes were performed to detect the presence of variability in the treatments under study, experimental precision and calculation of homogeneity of residual variances. For joint analysis, the homogeneity of variances was considered by Hartley's maximum $F$ test. The objective of this analysis was to estimate the significance of the environments, the interaction treatments $\mathrm{x}$ environments and the interaction of treatment outcomes (genotypes, checks and groups) with the environment. After interpretation the results were performed analyzes of individual and joint diallel variance proposed by Hayman (1954).

To test the adequacy of the data to the additive-dominant model, i.e., to verify if the data of each analyzed variable meets the restrictions imposed for the use of Hayman's genetic model, three tests were used: in the first one the variances and covariance were calculated. For each row in each of the repetitions and the variation between $W_{i}-V_{i}$ values of each repetition was evaluated by a randomized block analysis of variance, using as source of variation the blocks and rows of each diallel table. If the F test was not significant for the "lines" effect, it met the assumptions of the model.

In the second test, the significance of the angular coefficient of the line (b) was tested using an $F(=t 2)$ test with 1 and " $n-2$ " degrees of freedom. In the third test it was tested if the angular coefficient " $b$ " was 1.0, using the regression analysis of $W_{i}$ versus $V_{i}$ to obtain the mean square value of the regression deviation and then the variance of "b", then proceeding a $t$ test with "n2 "degrees of freedom. Since the angular coefficient of the line is nonzero and equal to 1.0 , it met the constraints of the model.

With the adequacy of the data to the additivedominant model, the results obtained from the diallel table were used to estimate the genetic variation components $\widetilde{H_{1}}, \widetilde{H_{2}}, \widetilde{D}, \widetilde{h^{2}}, \widetilde{F}$, where $\widetilde{H_{1}} \mathrm{e}$ $\widetilde{H_{2}}$ are the variation caused by the dominance effects; $\widetilde{D}$ is the measure of variation caused by additive gene effects; $\widetilde{h^{2}}$ the measure of variation caused by dominance effects; and $\tilde{F}$ is the mean covariance measure between additive and dominance gene effects.

The significance of each component was tested by the t-statistic, obtained by dividing the effect estimates by the respective standard deviation. When $\mathrm{t}$ values were above 1.98 , they 
were considered significant at $5 \%$ probability (Singh and Chaudhary, 1979). To calculate the standard deviation of each estimate, the variances of the components were obtained by consulting the table presented by Ferreira (1985).

The association between genetic variation components was also employed in the estimation of the following parameters:

$$
\left(\widetilde{H}_{1} / \widetilde{D}\right)^{1 / 2} \quad(\text { Eq. 1) }
$$

Is a measure of the average degree of dominance at all loci;

$$
\widetilde{H}_{2} / 4 \widetilde{H}_{1} \quad \text { (Eq. 2) }
$$

Is a measure of the average value of the products of the frequencies of positive and negative alleles at loci that exhibit dominance;

$$
K_{D} / K_{R}=\left(\sqrt{4 \widetilde{D} \widetilde{H}_{1}+\widetilde{F}}\right) /\left(\sqrt{4 \widetilde{D} \widetilde{H}_{1}-\widetilde{F}}\right)
$$

Is a measure of the most often occurring allele, where a ratio close to one (1) indicates equality between the number of dominant and recessive alleles in the parent genotypes;

$$
\tilde{h}^{2} / \widetilde{H}_{2} \quad \text { (Eq. 4) }
$$

Is a measure of the number of genes or gene blocks that control the character and display some degree of dominance;

$$
\tilde{h}_{R}^{2}=\left(\widetilde{D}-\widetilde{F}+\widetilde{H}_{1}-\widetilde{H}_{2}\right) /\left(\widetilde{D}-\widetilde{F}+\widetilde{H}_{1}-\frac{1}{2} \widetilde{H}_{2}+2 \tilde{\varepsilon}\right)
$$

Is a measure of the genotypic coefficient of determination in the narrow sense;

$$
\tilde{h}_{A}^{2}=\left(\widetilde{D}-\tilde{F}+\widetilde{H}_{1}-\frac{1}{2} \widetilde{H}_{2}\right) /\left(\widetilde{D}-\tilde{F}+\widetilde{H}_{1}-\frac{1}{2} \widetilde{H}_{2}+2 \tilde{\varepsilon}\right)
$$

(Eq. 6)

Is a measure of the genotypic coefficient of determination in the broad sense.
In addition to these parameters, the mean degree of dominance and relative genetic constitution of the parents were obtained by $W_{i}$ regression in $V_{i}$. All statistical analyzes were performed using Genes computer software (Cruz, 2013).

\section{Results and discussion Analysis of variance}

It is observed in the analysis of individual variance (Table 1) that there are significant differences between the average behavior of the lines at the $1 \%$ of probability by the $\mathrm{F}$ test for all environments, evidencing the existence of genetic variability, confirmed by the $C V_{g} / C V_{e}$ ratio, greater than 1 . The coefficients of variation showed good experimental accuracy for all environments, classified as low or medium as suggested by Scapim et al. (1995). The coefficients of variation for grain yield (YIELD) were considered average, which may be justified by the fact that it is a quantitative character, which makes it quite influential by the environment (Matos Filho et al., 2009).

The grain yield trait (GY) was not significant for the source of variation control, a fact linked to the low productivity of the lines (controls). It was observed that the general average of all environments was low for the productive patterns of the study region, which may be related to the presence of the parents in the trials, which presented productivities ranging from $345.11 \mathrm{~kg} \mathrm{ha}^{-1}$ to 2,359.57 $\mathrm{kg} \mathrm{ha}^{-1}$ (Table 2).

All variables meet the assumption of homogeneity of residual variances, allowing joint analysis of the data. However, the results of the joint analysis of variance (Table 3 ) show that the source of variation environment and the interaction treatment $\mathrm{x}$ environment and their outspread were significant for all variables, suggesting that the environments behaved differently with respect to the mean values genotype for all characters and/or that the performance of genotypes varied depending on the assessment environment, so individual analysis of each site is preferable.

\section{Diallelic analysis}

The restrictions imposed on the use of Hayman's method (1954) were evaluated by sufficiency tests of the additive-dominant model (Table 4) based on $\mathrm{W}_{\mathrm{i}}-\mathrm{V}_{\mathrm{i}}$ heterogeneity. The results 
show that, except for the humidity variable (HUM) in the medium environment, the genetic model was met in at least two tests for all variables. Similar results were presented by Schuelter et al. (2010) who, working with pepper plants, report adequacy of the studied variables to the genetic model in at least two tests.

The estimate of the average dominance degree $\left(\sqrt{H_{1}} / \mathrm{D}\right)$ for all variables was over 1.0 , indicating over-dominance, with the GY trait presenting the highest indices, reaching 11.3467 for the Palotina environment (PTNA) (Table 5). However, they do not agree with what was obtained from the $\mathrm{W}_{\mathrm{r}}$ graph in $\mathrm{V}_{\mathrm{r}}$ (Figures 1, 2, 3, 4 and 5), where the regression line cuts the $\mathrm{W}_{\mathrm{i}}$ axis above the origin, in most cases, showing possible partial dominance.

According to Cruz et al. (2012), the parameter $\mathrm{H}_{2} / 4 \mathrm{H}_{1}$ allows to evaluate the proportion of parents who are in dominant or recessive homozygosity, where values close to 0.25 indicate symmetrical distribution of alleles between parents. At this point, it is observed that only the trait GY tended to symmetry between parents, as it had values between 0.2262 to 0.2422 . From the $\mathrm{K}_{\mathrm{D}} / \mathrm{K}_{\mathrm{R}}$ ratio (Table 5), it can be concluded that the dominant alleles are more frequent in the parents of all characters, except for grain yield $(\mathrm{GY})$, which has a predominance of recessives, evidenced also by the $\mathrm{W}_{\mathrm{r}}$ in $\mathrm{V}_{\mathrm{r}}$ graph of this variable (Figure 03), which presents influence of recessivity.

Table 1. Mean squares of individual variance analysis for male flowering (MF), female flowering (FF), grain yield (GY), crop humidity (HUM) and mass of one thousand seed (MTS) of the 13 parents and their respective 78 hybrids.

\begin{tabular}{|c|c|c|c|c|c|c|c|}
\hline & \multirow{2}{*}{ SV } & \multirow{2}{*}{ DF } & \multicolumn{5}{|c|}{ MEAN SQUARE } \\
\hline & & & MF & FF & GY & HUM & MTS\# \\
\hline \multirow{10}{*}{$\begin{array}{l}\mathrm{N} \\
\stackrel{\vec{\alpha}}{\frac{\mathbf{\alpha}}{\Sigma}}\end{array}$} & BLOCKS & 2 & 9.20 & 7.92 & 1106786.03 & 3.11 & 1434.89 \\
\hline & TREATMENTS & 90 & $32.54^{* *}$ & $38.80^{* *}$ & $16405612.8^{* *}$ & $12.71^{* *}$ & $4327.23^{* *}$ \\
\hline & Genotye & 77 & $15.13^{* *}$ & $15.86^{* *}$ & $5292840.4^{* *}$ & $9.82^{* *}$ & $2517.30^{* *}$ \\
\hline & Check & 12 & $48.37^{* *}$ & $64.60^{* *}$ & $346801.8^{\text {ns }}$ & $15.59^{* *}$ & $3597.50^{* *}$ \\
\hline & Genotype vs Check & 1 & $1182.95^{\star *}$ & $1495.25^{* *}$ & $1064794815.6^{* *}$ & $200.98^{* *}$ & $152448.40^{* \star}$ \\
\hline & ERROR & 180 & 1.18 & 1.12 & 1066896.64 & 0.56 & 337.35 \\
\hline & TOTAL & 272 & & & & & \\
\hline & Average & & 59.72 & 59.99 & 6623.09 & 14.84 & 321.72 \\
\hline & $\mathrm{CV}(\%)$ & & 1.82 & 1.77 & 15.60 & 5.02 & 5.71 \\
\hline & $\mathrm{CVg} / \mathrm{CVe}$ & & 1.99 & 2.09 & 1.15 & 2.36 & 1.47 \\
\hline \multirow{10}{*}{ 悥 } & BLOCKS & 2 & 2.77 & 1.31 & 4267.81 & 12.32 & 134.23 \\
\hline & TREATMENTS & 90 & $18.37^{* *}$ & $28.63^{* *}$ & $10863288.7^{* *}$ & $34.06^{* *}$ & $6476.61^{* *}$ \\
\hline & Genotype & 77 & $13.56^{* *}$ & $19.81^{* *}$ & $3411106.4^{* *}$ & $36.44^{* *}$ & $4072.09^{* *}$ \\
\hline & Check & 12 & $14.60^{* *}$ & $25.58^{* *}$ & $793314.5^{\text {ns }}$ & $21.03^{* *}$ & $8695.30^{* *}$ \\
\hline & Genotype vs Check & 1 & $434.11^{* *}$ & $744.53^{* *}$ & $705521016.8^{* *}$ & $7.76^{\mathrm{ns}}$ & $164999.99^{* \star}$ \\
\hline & ERROR & 180 & 0.48 & 0.92 & 581338.76 & 2.99 & 251.79 \\
\hline & TOTAL & 272 & & & & & \\
\hline & Average & & 52.63 & 53.39 & 4953.92 & 22.33 & 261.55 \\
\hline & $\mathrm{CV}(\%)$ & & 1.31 & 1.80 & 15.39 & 7.75 & 6.07 \\
\hline & $\mathrm{CVg} / \mathrm{CVe}$ & & 3.03 & 2.61 & 1.27 & 1.93 & 2.25 \\
\hline \multirow{10}{*}{ 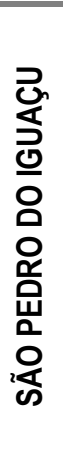 } & BLOCKS & 2 & 5.08 & 2.00 & 3203730.1 & 0.56 & \\
\hline & TREATMENTS & 90 & $32.14^{* *}$ & $42.20^{* *}$ & $6679031.2^{* *}$ & $42.98^{* *}$ & \\
\hline & Genotype & 77 & $16.71^{* *}$ & $22.66^{* *}$ & $2235917.3^{* *}$ & $44.03^{* *}$ & \\
\hline & Check & 12 & $52.94^{* *}$ & $50.61^{* *}$ & $961514.7^{\mathrm{ns}}$ & $38.09^{* *}$ & \\
\hline & Genotype vs Check & 1 & $970.77^{\star *}$ & $1445.55^{\star *}$ & $417409003.9^{* *}$ & $21.11^{\mathrm{ns}}$ & \\
\hline & ERROR & 180 & 3.61 & 4.68 & 491127.7 & 2.62 & \\
\hline & TOTAL & 272 & & & & & \\
\hline & Average & & 58.71 & 59.92 & 4445.69 & 25.37 & \\
\hline & CV(\%) & & 3.24 & 3.61 & 15.76 & 6.38 & \\
\hline & $\mathrm{CVg} / \mathrm{CVe}$ & & 1.10 & 1.13 & 1.09 & 2.29 & \\
\hline
\end{tabular}

**: Significant at $1 \%$ of probability by $\mathrm{F}$ test; ns: not significant; $\mathrm{CV}(\%)$ : coefficient of variation; $\mathrm{CVg} / \mathrm{CVe}$ : ratio between genetic and environmental variation. ${ }^{\#}$ : Performed only in Mariluz and Palotina. 
Table 2. Mean values of male flowering (MF), female flowering (FF), grain yield (GY), crop humidity (HUM) and mass of one thousand seed (MTS) of the 13 parents.

\begin{tabular}{|c|c|c|c|c|c|c|}
\hline & Parental & MF (days) & FF (days) & GY (kg ha-1) & HUM (\%) & MTS\# $^{\prime}(g)$ \\
\hline \multirow{13}{*}{$\frac{N}{\stackrel{N}{\mathcal{\alpha}}}$} & CD069 & $59.33 d$ & $60.00 \mathrm{e}$ & 1762.52ab & $11.17 \mathrm{cde}$ & $208.15 \mathrm{e}$ \\
\hline & CD060 & $68.67 a$ & $68.67 a b c$ & 1863.60ab & $17.58 \mathrm{a}$ & 287.02abc \\
\hline & CD056 & $66.00 \mathrm{ab}$ & $67.00 \mathrm{abc}$ & $1122.75 b$ & $10.33 e$ & $319.36 a$ \\
\hline & CD007 & $65.67 a b c$ & $64.67 \mathrm{~cd}$ & 1332.09ab & $10.82 \mathrm{de}$ & 239.99bcde \\
\hline & CD070 & $59.67 d$ & $59.00 \mathrm{e}$ & 1747.34ab & 11.36cde & $220.35 \mathrm{de}$ \\
\hline & CD065 & $67.00 \mathrm{a}$ & 69.00ab & 1497.31ab & 11.42cde & 235.93bcde \\
\hline & CD008 & $68.67 a$ & $70.33 a$ & 2023.76ab & $14.07 \mathrm{bc}$ & 262.68abcde \\
\hline & CD010 & $62.33 \mathrm{bcd}$ & $65.67 \mathrm{bc}$ & 2035.96ab & 12.19cde & 265.06abcde \\
\hline & CD067 & $61.67 \mathrm{~cd}$ & $60.67 \mathrm{de}$ & $2359.57^{\mathrm{a}}$ & $11.98 \mathrm{cde}$ & 273.49abcd \\
\hline & CD038 & $69.67 a$ & $71.00 \mathrm{a}$ & $1762.01 \mathrm{ab}$ & 16.79ab & $280.05 \mathrm{abcd}$ \\
\hline & CD063 & $67.33 a$ & $69.67 a b$ & 1862.89ab & $13.89 \mathrm{bcd}$ & $300.37 a b$ \\
\hline & CD072 & $58.33 d$ & $58.67 e$ & $2202.90 \mathrm{ab}$ & $12.94 \mathrm{cde}$ & $305.40 \mathrm{a}$ \\
\hline & CD034 & $68.33 a$ & $70.00 a$ & 1639.10ab & $11.04 \mathrm{cde}$ & $232.08 \mathrm{cde}$ \\
\hline \multirow{13}{*}{ 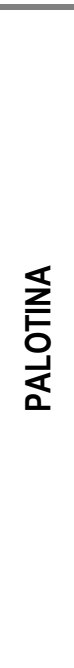 } & CD069 & $52.33 d$ & $53.00 \mathrm{~d}$ & 1059.88abcde & $17.63 f$ & $165.77 \mathrm{~cd}$ \\
\hline & CD060 & $57.00 \mathrm{ab}$ & $60.00 a$ & $662.87 \mathrm{cde}$ & 19.75def & $155.27 \mathrm{de}$ \\
\hline & CD056 & $57.00 \mathrm{ab}$ & $60.00 a$ & $345.11 \mathrm{e}$ & $21.69 \mathrm{bcd}$ & $195.47 \mathrm{bcd}$ \\
\hline & CD007 & $57.00 \mathrm{ab}$ & $59.00 \mathrm{ab}$ & 1166.02abcde & $22.45 \mathrm{bcd}$ & 197.17bcd \\
\hline & CD070 & $52.00 \mathrm{~d}$ & $52.67 d$ & $1630.46 \mathrm{ab}$ & $22.74 \mathrm{bcd}$ & $193.40 \mathrm{bcd}$ \\
\hline & CD065 & $56.00 \mathrm{bc}$ & $58.00 \mathrm{~b}$ & 493.94de & 18.50ef & $102.90 \mathrm{e}$ \\
\hline & CD008 & $58.00 \mathrm{a}$ & $60.00 a$ & 460.16de & $24.40 \mathrm{ab}$ & $182.43 \mathrm{bcd}$ \\
\hline & CD010 & $56.00 \mathrm{bc}$ & $58.00 \mathrm{~b}$ & 775.00 bcde & $20.87 \mathrm{cde}$ & $217.80 \mathrm{bc}$ \\
\hline & CD067 & $55.00 \mathrm{c}$ & $55.00 \mathrm{c}$ & $1928.55 a$ & 19.73def & $195.77 \mathrm{bcd}$ \\
\hline & CD038 & $58.00 a$ & $60.00 a$ & 1419.48abc & $27.15 a$ & 288.63a \\
\hline & CD063 & $57.00 \mathrm{ab}$ & $59.00 \mathrm{ab}$ & $487.85 \mathrm{de}$ & $24.4 a b$ & $314.23 a$ \\
\hline & CD072 & $52.00 \mathrm{~d}$ & $53.00 d$ & 1357.90abcd & $21.95 \mathrm{bcd}$ & $220.83 b$ \\
\hline & CD034 & $57.00 \mathrm{ab}$ & $59.00 \mathrm{ab}$ & $1422.83 a b c$ & $23.57 \mathrm{bc}$ & $187.70 \mathrm{bcd}$ \\
\hline \multirow{13}{*}{ 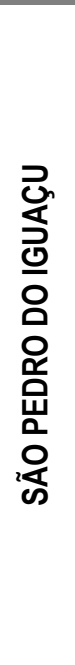 } & CD069 & $57.33 d$ & 62.33abcd & 1037.28ab & $23.06 \mathrm{~b}$ & \\
\hline & CD060 & 63.00abcd & 64.67abcd & $2332.26 a$ & $23.72 b$ & \\
\hline & CD056 & $66.42 \mathrm{abc}$ & $70.42 a$ & $593.34 b$ & $23.07 \mathrm{~b}$ & \\
\hline & CD007 & 63.50abcd & 65.50abcd & 2123.57ab & $35.11 a$ & \\
\hline & $\mathrm{CD} 070$ & $58.00 \mathrm{~cd}$ & $59.67 d$ & $870.44 a b$ & $21.33 b$ & \\
\hline & CD065 & 64.67abcd & 68.00abcd & $1052.84 a b$ & $21.87 \mathrm{~b}$ & \\
\hline & CD008 & $69.00 \mathrm{a}$ & 70.00ab & 1348.13ab & $25.73 b$ & \\
\hline & CD010 & 64.00abcd & 69.00abcd & 1197.61ab & $23.25 b$ & \\
\hline & CD067 & 63.00abcd & 62.33abcd & 1147.98ab & $22.55 b$ & \\
\hline & CD038 & $60.00 \mathrm{bcd}$ & $60.33 \mathrm{~cd}$ & $2243.77 a$ & $22.84 b$ & \\
\hline & CD063 & 67.33ab & $69.67 a b c$ & 1105.89ab & $25.42 b$ & \\
\hline & CD072 & $57.33 d$ & $60.67 \mathrm{bcd}$ & $1360.47 a b$ & $26.60 \mathrm{~b}$ & \\
\hline & CD034 & $69.67 a$ & 69.67abc & $2005.57 a b$ & $26.41 b$ & \\
\hline
\end{tabular}

* Means followed by the same letter in the column did not differ statistically by the Tukey test at $5 \%$ significance. ${ }^{*}$ : Performed only in Mariluz and Palotina. 
Table 3. Mean squares of joint analysis of variance, following the simple factorial model with additional checks for male flowering (MF), female flowering (FF), grain yield (GY), harvest humidity (HUM) in Palotina, Mariluz and São Pedro do Iguaçu and mass of one thousand seeds (MTS) in Pallottine and São Pedro do Iguaçu.

\begin{tabular}{|c|c|c|c|c|c|c|c|}
\hline \multirow{2}{*}{ SV } & \multirow{2}{*}{ DF } & \multicolumn{4}{|c|}{ MEAN SQAURES } & \multirow{2}{*}{ DF } & \multirow{2}{*}{$\begin{array}{c}\text { MEAN SQUARE } \\
\text { MTS\# }\end{array}$} \\
\hline & & MF & FF & GY & HUM & & \\
\hline BLOCK/ENVIRONMENT & 6 & 5.68 & 3.74 & 1438261.32 & 5.33 & 4 & 784.56 \\
\hline BLOCK & 2 & 4.60 & 7.05 & 442322.01 & 9.49 & 2 & 466.64 \\
\hline BLOCK vs ENVIRONMENT & 4 & 6.22 & 2.09 & 1936230.98 & 3.25 & 2 & 1102.48 \\
\hline TREATMENT & 90 & $74.45^{\star \star}$ & $99.92^{* *}$ & $28584936.06^{\star \star}$ & $52.35^{* \star}$ & 90 & $8711.06^{\star *}$ \\
\hline Genotypes & 77 & $40.21^{* *}$ & $52.46^{* *}$ & $5814088.77^{* \star}$ & $54.35^{\star *}$ & 77 & $4691.74^{\star *}$ \\
\hline Check & 12 & $93.09^{* \star}$ & $112.51^{* *}$ & 971881.12 & 30.95 & 12 & $8783.97^{*}$ \\
\hline Groups & 1 & $2487.54^{*}$ & $3603.60^{*}$ & $2113296836.79^{*}$ & 154.91 & 1 & $317324.27^{* *}$ \\
\hline ENVIRONMENTS & 2 & $4016.85^{\star *}$ & $3919.36^{* *}$ & $354241706.46^{\star \star}$ & $8017.28^{* *}$ & 1 & $494182.53^{* *}$ \\
\hline TREATMENT vs ENVIRONMENT & 180 & $4.30^{\star *}$ & $4.85^{* *}$ & $2681498.32^{* \star}$ & $18.71^{* *}$ & 90 & $2092.77^{\star \star}$ \\
\hline Genotype x Environments & 154 & $2.60^{\star *}$ & $2.94^{*}$ & $2562887.66^{* *}$ & $17.97^{\star *}$ & 77 & $1897.66^{\star \star}$ \\
\hline Tester $\mathrm{x}$ Environments & 24 & $11.41^{* *}$ & $14.14^{* \star}$ & 564874.93 & $21.88^{* \star}$ & 12 & $3508.83^{\star \star}$ \\
\hline Groups $x$ Environments & 2 & $50.14^{* *}$ & $40.87^{* \star}$ & $37213999.75^{\star *}$ & $37.47^{\star *}$ & 1 & $124.12^{* *}$ \\
\hline ERROR & 540 & 1.75 & 2.24 & 713121.03 & 2.06 & 360 & 294.57 \\
\hline TOTAL & 818 & & & & & 545 & \\
\hline Average & & 57.02 & 57.77 & 5340.90 & 20.84 & & 291.64 \\
\hline CV $(\%)$ & & 2.32 & 2.59 & 15.81 & 6.88 & & 5.89 \\
\hline
\end{tabular}

ns: not significant; *, **: Significant at 5\% and 1\% probability; CV (\%): coefficient of variation; \#: Performed only in Mariluz and Palotina.

Table 4. Suitability test of the additive-dominant model based on the analysis of variance of $\mathrm{W}_{\mathrm{i}}-\mathrm{V}_{\mathrm{i}}$ values and the linear regression analysis of $\mathrm{W}_{\mathrm{i}}$ in relation to $\mathrm{V}_{\mathrm{i}}$ for male flowering (MF), female flowering (FF), grain yield (GY), crop humidity (HUM) of Mariluz, São Pedro do Iguaçu and Palotina and mass of one thousand seeds (MTS) of Mariluz and Palotina.

\begin{tabular}{|c|c|c|c|c|}
\hline \multirow{2}{*}{ Trait } & \multirow{2}{*}{ Env. } & \multirow{2}{*}{$\begin{array}{c}\text { ANOVA }\left(\mathrm{W}_{\mathrm{i}}-\mathrm{V}_{\mathrm{i}}\right)^{\#} \\
\text { Mean Square }\end{array}$} & \multicolumn{2}{|c|}{ Regression $\left[W_{i}=1 / 4\left(D-H_{1}\right)+b V_{i}\right]^{\#}$} \\
\hline & & & $t\left(H_{0}: b=1\right)$ & $t^{2}\left(H_{0}: b^{\prime}=0\right)$ \\
\hline \multirow{4}{*}{ GY $\left(\mathrm{kg} \mathrm{ha}^{-1}\right)$} & MLZ & $57521880807.64^{\mathrm{ns}}$ & 0.109 ns & $6.696^{*}$ \\
\hline & SPI & $427002169724.76^{*}$ & 0.609 ns & $0.737^{\mathrm{ns}}$ \\
\hline & PTNA & $87934573054.77^{\mathrm{ns}}$ & $0.117 \mathrm{~ns}$ & $6.015^{*}$ \\
\hline & Average & $29997786024.48^{\mathrm{ns}}$ & $0.138^{\text {ns }}$ & $3.531^{\text {ns }}$ \\
\hline \multirow{4}{*}{ HUM (\%) } & MLZ & $2.99^{*}$ & $0.404^{\text {ns }}$ & $1.845^{\text {ns }}$ \\
\hline & SPI & $100.88^{*}$ & $0.395^{\text {ns }}$ & $4.056^{\text {ns }}$ \\
\hline & PTNA & $25.57^{*}$ & 0.549 ns & $2.072^{\mathrm{ns}}$ \\
\hline & Average & $4.29^{*}$ & $0.274^{\text {ns }}$ & $4.937^{*}$ \\
\hline \multirow{3}{*}{ MTS (g) } & MLZ & $375944.99^{*}$ & $0.444^{\mathrm{ns}}$ & $2.672^{\text {ns }}$ \\
\hline & PTNA & $1155970.09^{*}$ & $0.619^{n s}$ & $0.353^{\text {ns }}$ \\
\hline & Average & $396623.57^{\star}$ & $0.458^{\mathrm{ns}}$ & $1.266^{\mathrm{ns}}$ \\
\hline \multirow{4}{*}{ MF (days) } & MLZ & $81.87^{*}$ & $0.733^{\text {ns }}$ & $2.714^{\mathrm{ns}}$ \\
\hline & SPI & $85.76^{*}$ & $0.673^{\text {ns }}$ & $1.59^{\mathrm{ns}}$ \\
\hline & PTNA & $4.76^{*}$ & 0.429 ns & $2.743^{\text {ns }}$ \\
\hline & Average & $36.36^{*}$ & $0.720^{\text {ns }}$ & $2.404^{\text {ns }}$ \\
\hline \multirow{4}{*}{ FF (days) } & MLZ & $127.78^{*}$ & $0.677^{\mathrm{ns}}$ & $4.178^{\text {ns }}$ \\
\hline & SPI & $90.31^{*}$ & $0.537 \mathrm{~ns}$ & $1.723^{\mathrm{ns}}$ \\
\hline & PTNA & $21.80^{*}$ & $0.567^{\mathrm{ns}}$ & $2.449 \mathrm{~ns}$ \\
\hline & Average & $66.43^{*}$ & $0.699 \mathrm{~ns}$ & $2.498^{\mathrm{ns}}$ \\
\hline
\end{tabular}

ns. not significant; *: Significant at 5\% probability; $\left({ }^{\#}: \mathrm{F}\right.$ Test ; ${ }^{\#}: \mathrm{t}$ Test); $\mathrm{t}^{2}$ : $\mathrm{t}$ test, considering the mean values of $\mathrm{W}_{\mathrm{i}}$ and $\mathrm{V}_{\mathrm{i}}$ for a $45^{\circ}$ rotation; Env: Environment. 
a)

$W r \quad W r^{2}=21.53 \mathrm{Vr} \quad W r=.09+.67 \mathrm{Vr}$

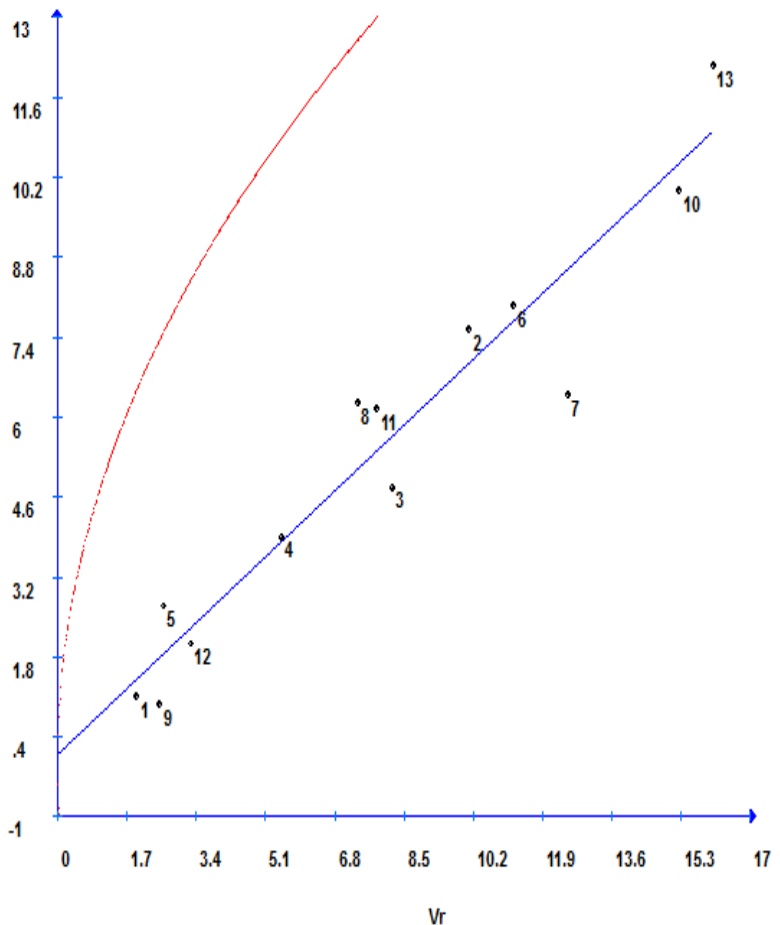

c)

$W r \quad W r^{2}=8.52 \mathrm{Vr} \quad W r=.31+.56 \mathrm{Vr}$

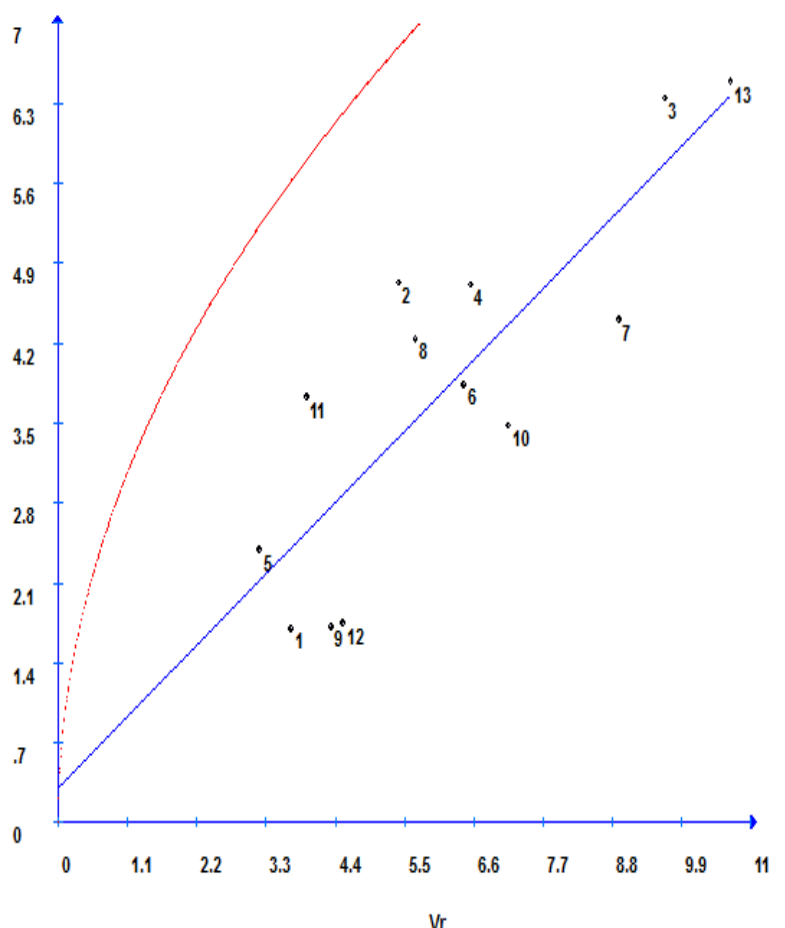

b)

$\mathrm{Wr} \quad W r^{2}=21.53 \mathrm{Vr} \quad \mathrm{Wr}=.09+.67 \mathrm{Vr}$

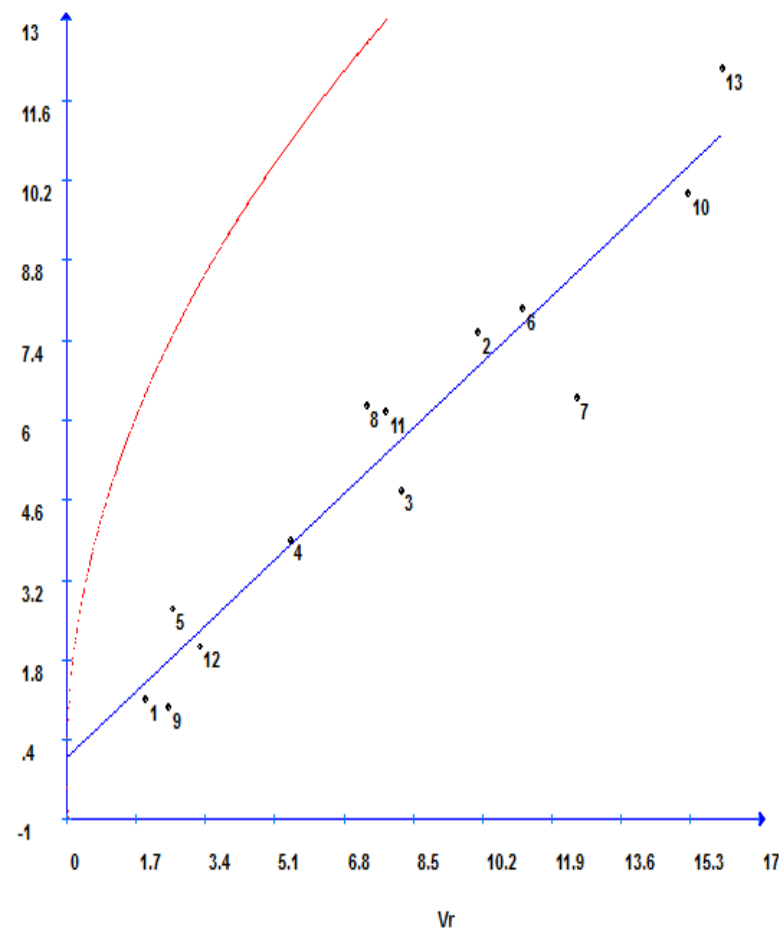

d)

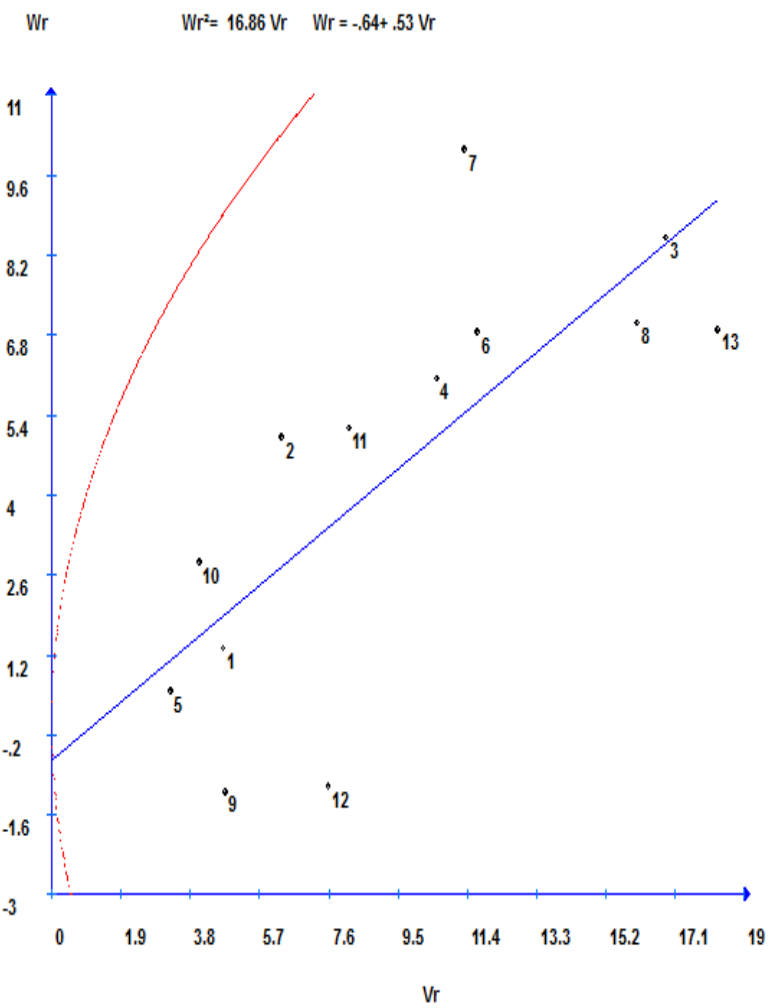

Figure 1. Regressions of $\mathrm{W}_{\mathrm{r}}$ in $\mathrm{V}_{\mathrm{r}}$ for female floewring (FF) for joint analysis (a), Mariluz (b), Palotina (c) and São Pedro do Iguaçu (d). 1: CD069; 2: CD060; 3: CD056; 4: CD007; 5: CD070; 6: CD065; 7: CD008; 8: CD010; 9: CD067; 10: CD038; 11: CD063; 12: CD072; and13: CD034. 
a)

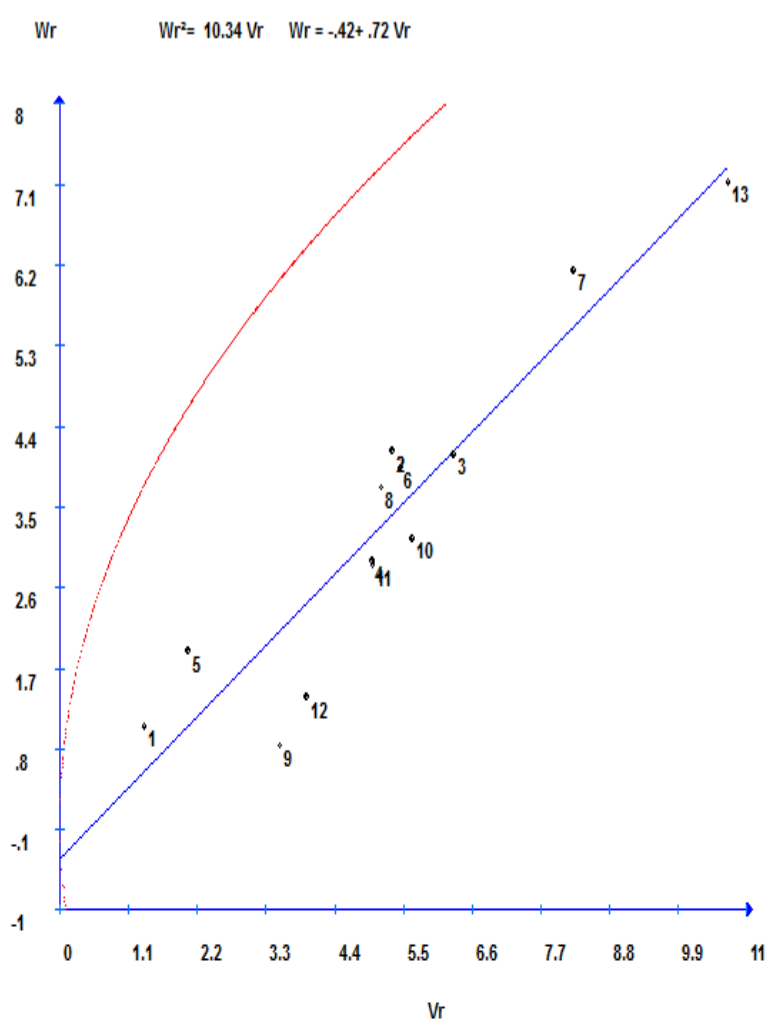

c)

Wr $\quad W r^{2}=4.86 \mathrm{Vr} \quad W r=.51+.42 \mathrm{Vr}$

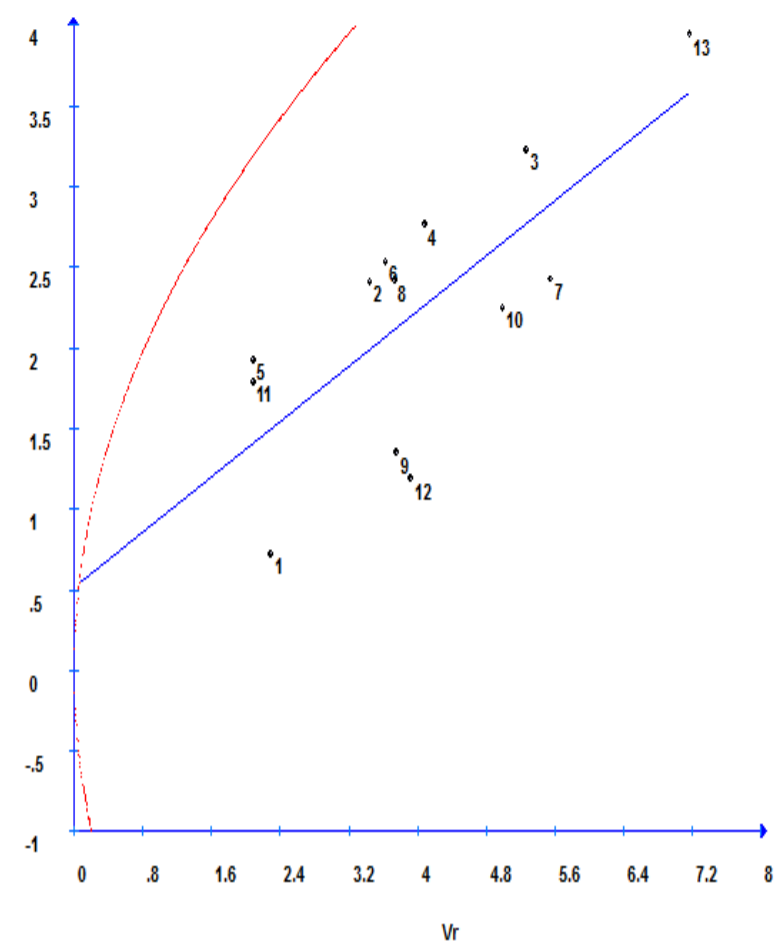

b)

$\mathrm{Wr} \quad \mathrm{Wr} \mathrm{r}^{2}=16.12 \mathrm{Vr} \quad \mathrm{Wr}=-., 64+.73 \mathrm{Vr}$

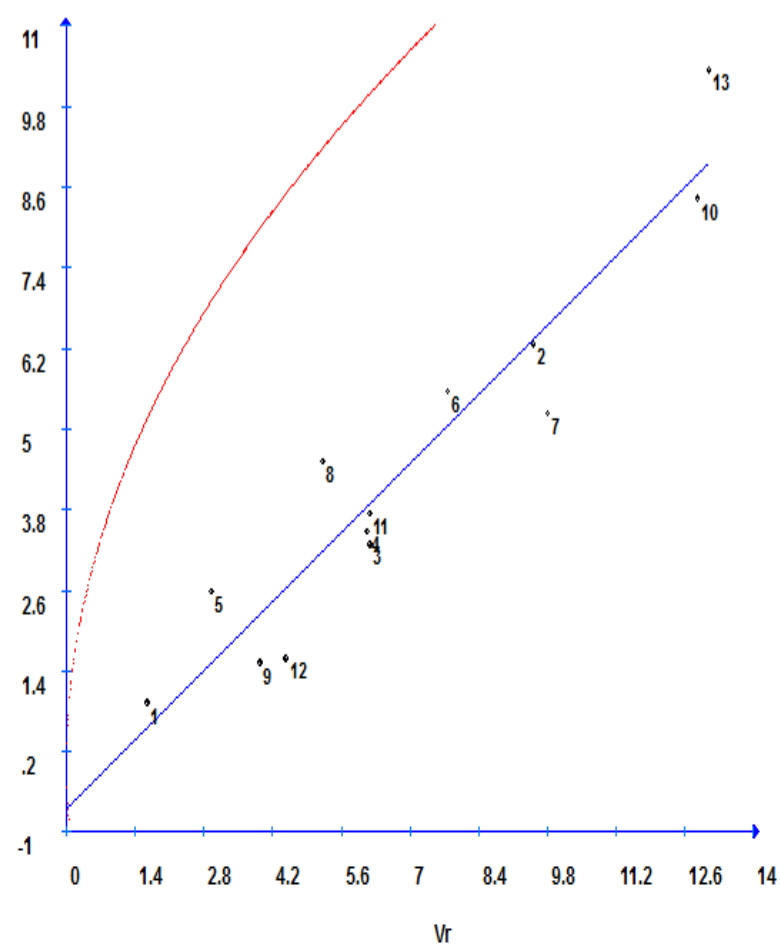

d)

Wr $\quad W r^{2}=17.64 \mathrm{Vr} \quad \mathrm{Wr}=-.55+.67 \mathrm{Vr}$

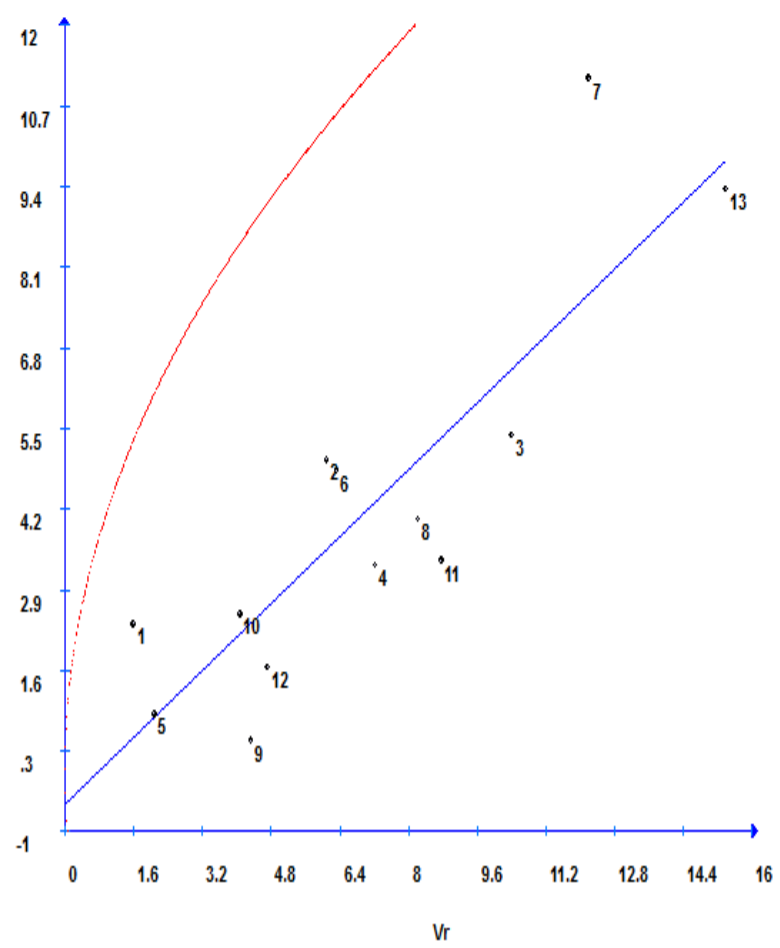

Figure 2. Regressions of $\mathrm{W}_{\mathrm{r}}$ in $\mathrm{V}_{\mathrm{r}}$ for male flowering (MF) for the joint analysis (a), Mariluz (b), Palotina (c) and São Pedro do Iguaçu (d). 1: CD069; 2: CD060; 3: CD056; 4: CD007; 5: CD070; 6: CD065; 7: CD008; 8: CD010; 9: CD067; 10: CD038; 11: CD063; 12: CD072; and 13: CD034. 


\section{a)}

$W r \quad W r^{2}=107986.79 \mathrm{Vr} \quad \mathrm{Wr}=-255960.84+.13 \mathrm{Vr}$

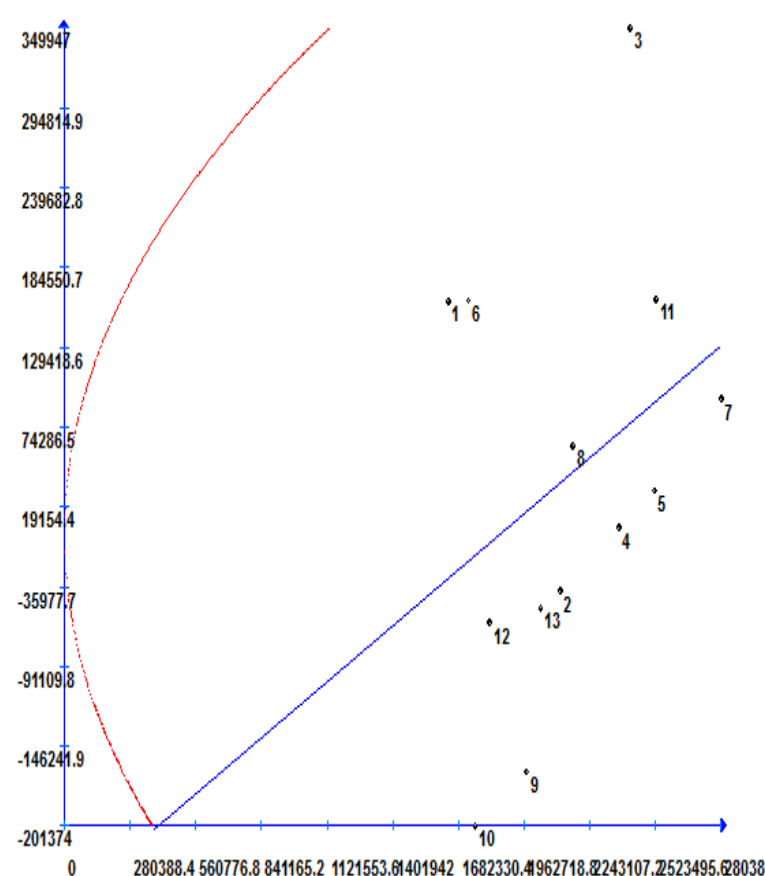

$\mathrm{Vr}$

c)

Wr $\quad W r^{2}=264438.15 \mathrm{Vr} \quad \mathrm{Wr}=-225699.28+.11 \mathrm{Vr}$

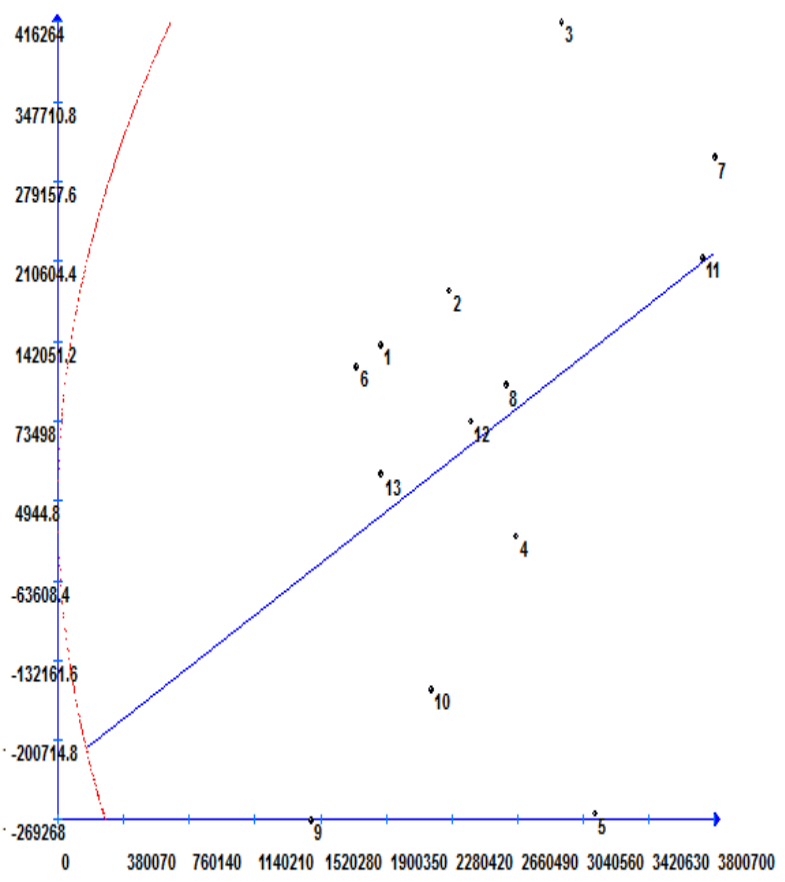

Vr b)

Wr $\quad W r^{2}=115600.6 \mathrm{Vr} \quad \mathrm{Wr}=-405933.3+.1 \mathrm{Vr}$

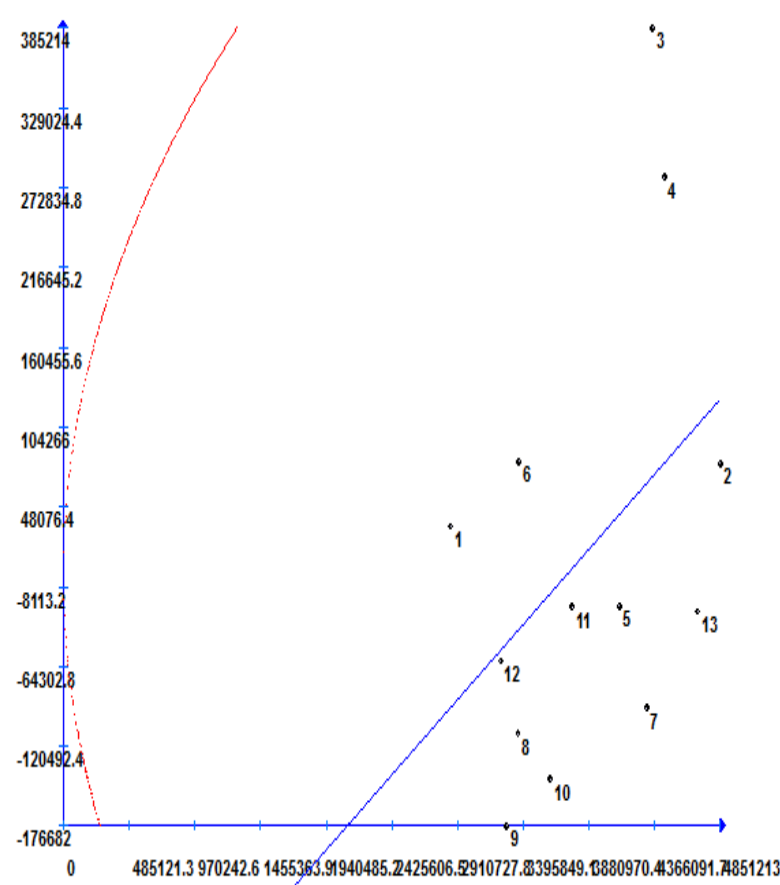

$\mathrm{Vr}$
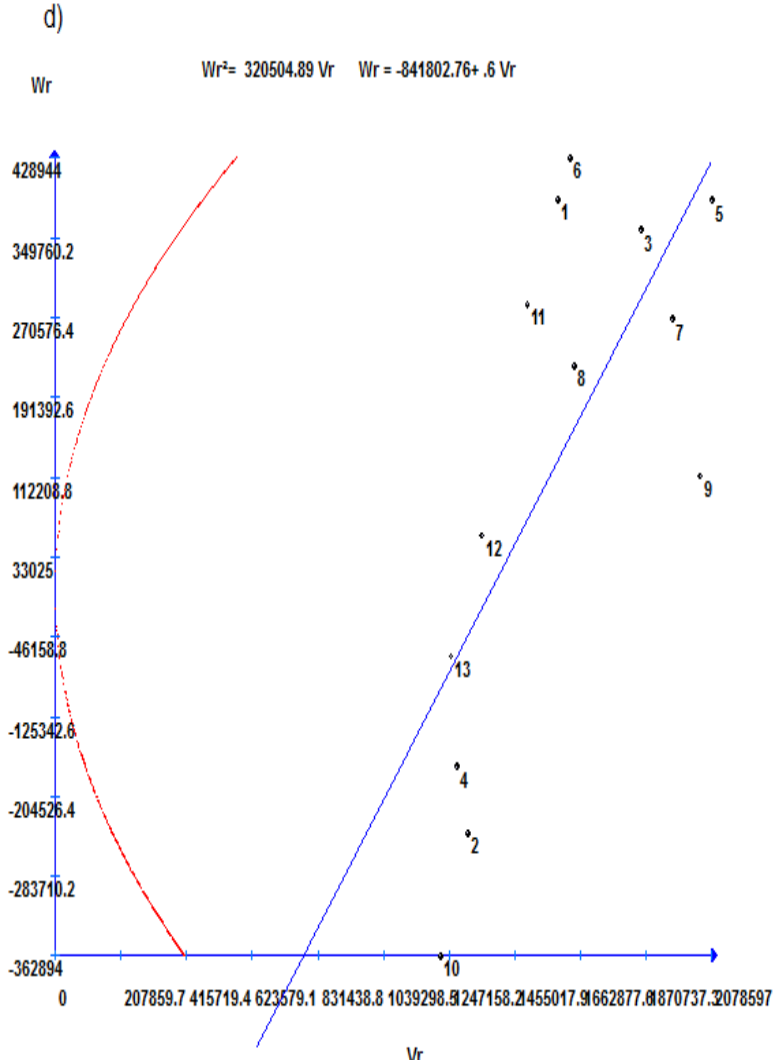

$\mathrm{Vr}$

Figure 3. Regressions of $\mathrm{W}_{\mathrm{r}}$ in $\mathrm{V}_{\mathrm{r}}$ for grain yield (GY) for the joint analysis (a), Mariluz (b), Palotina (c) and São Pedro do Iguaçu (d). 1: CD069; 2: CD060; 3: CD056; 4: CD007; 5: CD070; 6: CD065; 7: CD008; 8: CD010; 9: CD067; 10: CD038; 11: CD063; 12: CD072; and13: CD034. 


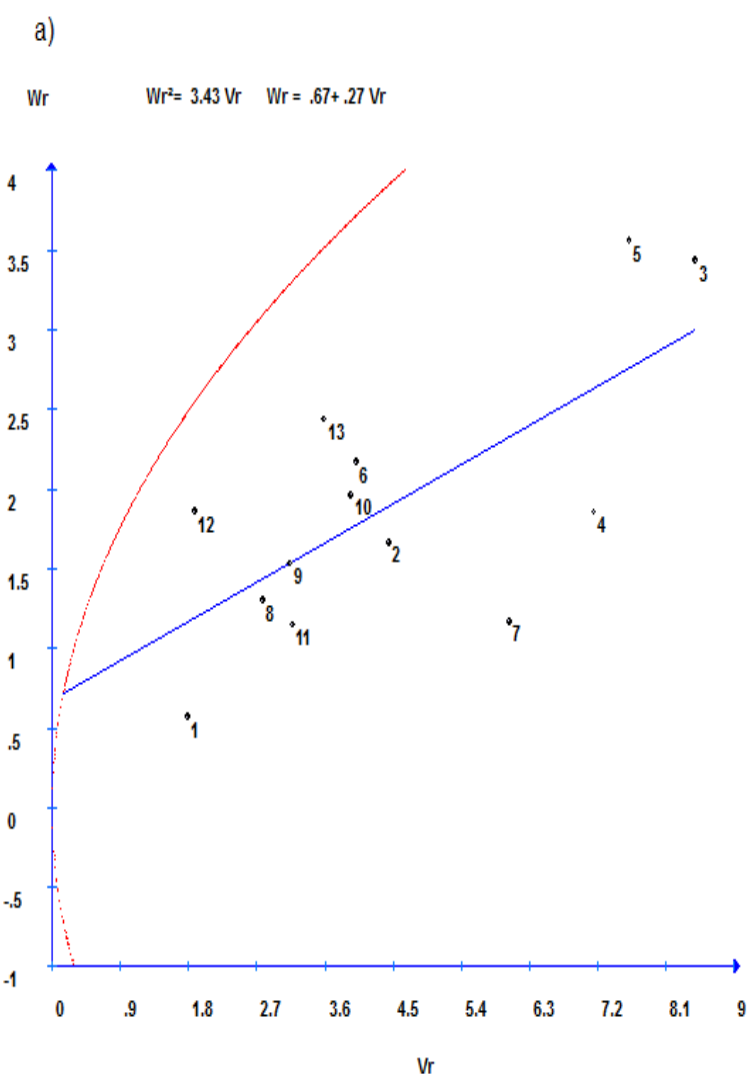

c)

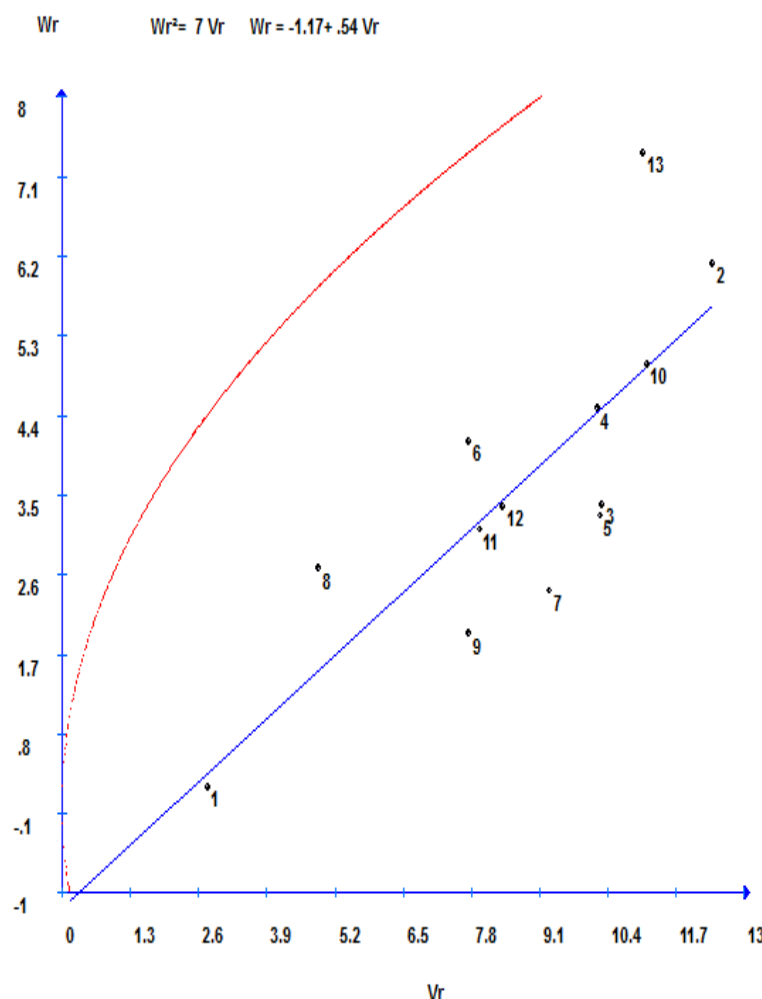

b)

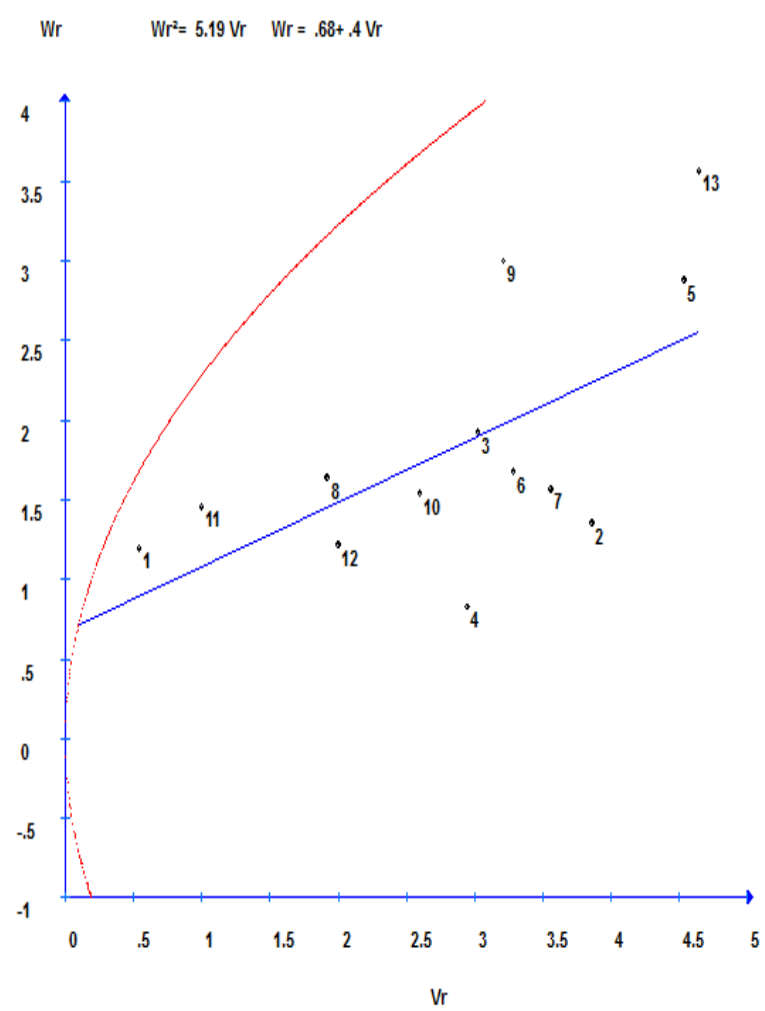

d)

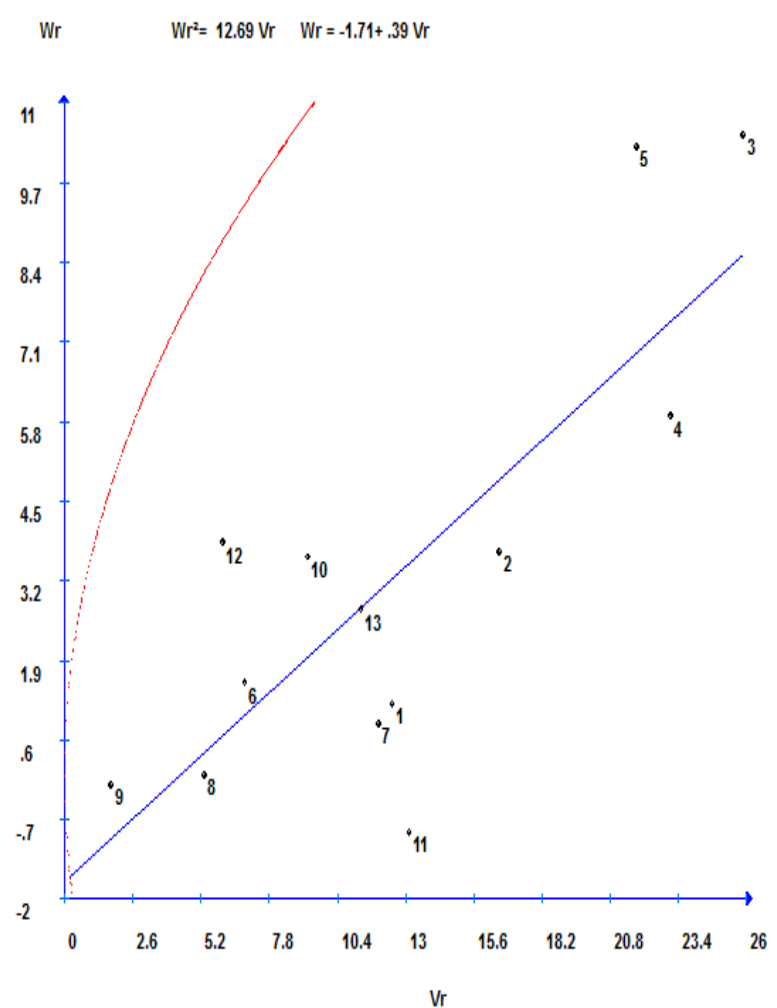

Figure 4. Regressions of $\mathrm{W}_{\mathrm{r}}$ in $\mathrm{V}_{\mathrm{r}}$ for crop humidity (HUM) for the joint analysis (a), Mariluz (b), Palotina (c) and São Pedro do Iguaçu (d). 1: CD069; 2: CD060; 3: CD056; 4: CD007; 5: CD070; 6: CD065; 7: CD008; 8: CD010; 9: CD067; 10: CD038; 11: CD063; 12: CD072; and 13: CD034. 
a) b)

$W r \quad W r^{2}=1463.99 \mathrm{Vr} \quad W r=-188.67+.45 \mathrm{Vr}$

Wr $\quad W r^{2}=1199.16 \mathrm{Vr} \quad \mathrm{Wr}=-379.64+.44 \mathrm{Vr}$

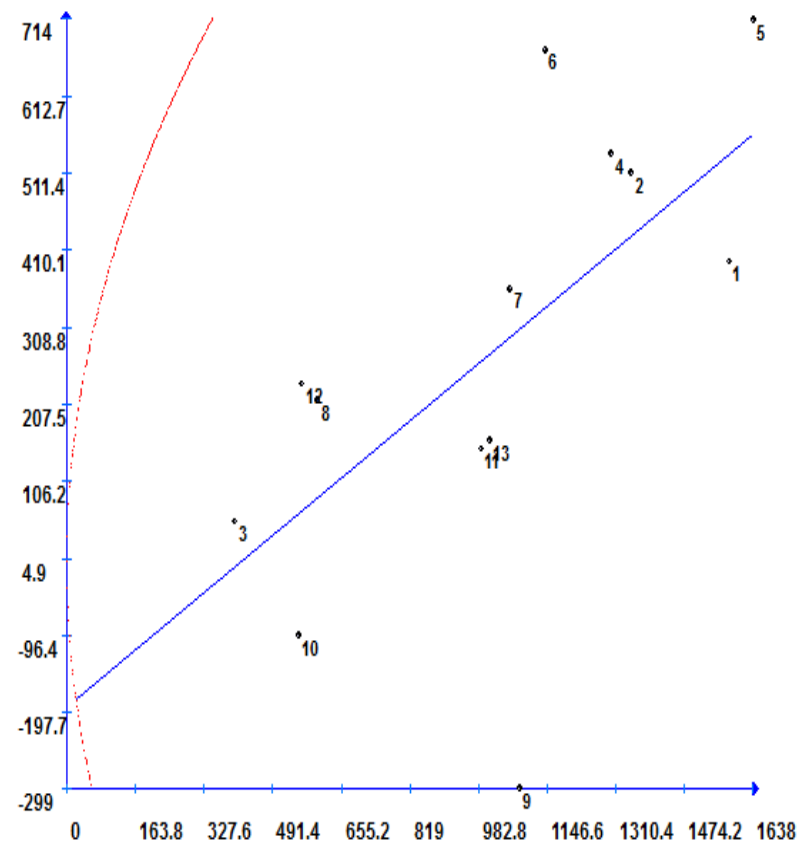

$\mathrm{Vr}$

c)

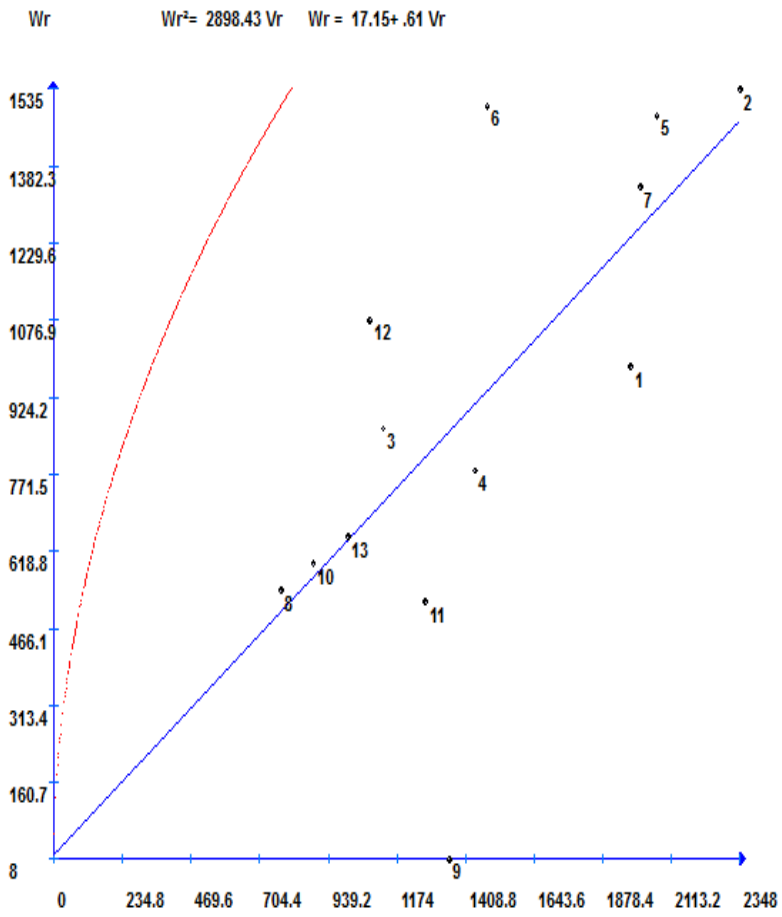

$\mathrm{Vr}$

Figure 5. Regressions of $\mathrm{W}_{\mathrm{r}}$ in $\mathrm{V}_{\mathrm{r}}$ for mass of one thousand seeds (MTS) for the joint analysis (a), Mariluz (b) and Palotina. 1: CD069; 2: CD060; 3: CD056; 4: CD007; 5: CD070; 6: CD065; 7: CD008; 8: CD010; 9: CD067; 10: CD038; 11: CD063; 12: CD072; and13: CD034. 
Table 5. Estimates of genetic and non-genetic parameters for male flowering (MF), female flowering (FF), grain yield (GY), crop humidity (HUM) of Mariluz, São Pedro do Iguaçu and Palotina and mass of a thousand seeds (MTS) of Mariluz and Palotina.

\begin{tabular}{|c|c|c|c|c|c|c|c|}
\hline \multirow{2}{*}{ Trait } & \multirow{2}{*}{ Env. } & \multicolumn{6}{|c|}{ Parâmetros } \\
\hline & & $\sqrt{ } \mathrm{H}_{1} / \mathrm{D}$ & $\mathrm{H}_{2} / 4 \mathrm{H}_{1}$ & $K_{D} / K_{R}$ & $h^{2} / H_{2}$ & $h^{2}{ }_{R}$ & $h^{2}{ }_{A}$ \\
\hline \multirow{4}{*}{ MF (days) } & MLZ & 1.2402 & 0.1858 & 2.1055 & 6.7012 & 0.4518 & 0.9560 \\
\hline & SPI & 1.1915 & 0.1642 & 2.4577 & 6.4330 & 0.4407 & 0.8663 \\
\hline & PTNA & 1.5415 & 0.1798 & 1.0783 & 5.4936 & 0.6272 & 0.9728 \\
\hline & Average & 1.2678 & 0.1827 & 1.7249 & 7.2194 & 0.5322 & 0.9447 \\
\hline \multirow{4}{*}{ FF (days) } & MLZ & 1.1856 & 0.1807 & 2.3618 & 7.0870 & 0.4414 & 0.9636 \\
\hline & SPI & 1.3925 & 0.1840 & 1.9020 & 6.7250 & 0.4135 & 0.8697 \\
\hline & PTNA & 1.4157 & 0.1907 & 1.1171 & 6.0332 & 0.6110 & 0.9653 \\
\hline & Average & 1.3531 & 0.1970 & 1.5623 & 6.8011 & 0.5230 & 0.9979 \\
\hline \multirow{4}{*}{ GY (kg ha-1) } & MLZ & - & 0.2306 & - & 8.5071 & 0.1515 & 0.9148 \\
\hline & SPI & 5.8714 & 0.2422 & 0.8520 & 8.1180 & 0.1384 & 0.9042 \\
\hline & PTNA & 11.3467 & 0.2262 & 0.9215 & 8.7314 & 0.1820 & 0.9296 \\
\hline & Average & 8.8841 & 0.2369 & 1.0634 & 8.8933 & 0.1094 & 0.9999 \\
\hline \multirow{4}{*}{ HUM (\%) } & MLZ & 1.2951 & 0.1758 & 1.5351 & 3.5432 & 0.6013 & 0.9546 \\
\hline & SPI & 1.9768 & 0.1973 & 1.5895 & 0.0517 & 0.3535 & 0.9434 \\
\hline & PTNA & 1.9480 & 0.1787 & 0.8221 & 0.2983 & 0.5933 & 0.9201 \\
\hline & Average & 1.9928 & 0.1881 & 0.8946 & 0.5147 & 0.5942 & 0.9969 \\
\hline \multirow{3}{*}{ MTS (g) } & MLZ & 2.0529 & 0.1638 & 2.4328 & 4.6968 & 0.3490 & 0.9997 \\
\hline & PTNA & 1.3180 & 0.1891 & 1.7801 & 4.4164 & 0.5096 & 0.9998 \\
\hline & Average & 1.7393 & 0.1980 & 2.1094 & 5.1306 & 0.3689 & 0.9997 \\
\hline
\end{tabular}

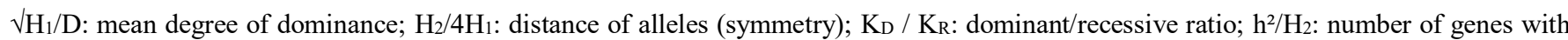
dominance; $h^{2} \mathrm{R}$ : coeficiente of determination in then arrow sense; $\mathrm{h}^{2} \mathrm{~A}$ : coeficiente of determination in the broad sense. -: unable to estimate the parameter; Env: Environment.

The results of $\mathrm{h}^{2} / \mathrm{H}_{2}$ indicate a high number of genes in dominance within the lines used for all variables except humidity (HUM), where the values do not indicate dominance for this trait. Amaral Junior et al. (1999) reported low reliability and low robustness of the results of the $h^{2} / \mathrm{H}_{2}$ statistics, where they found atypicalities in the results. Similarly, it is observed that for the humidity variable (HUM) the $\sqrt{ }_{\mathrm{H}_{1}} / \mathrm{D}$ estimator indicates overdominance and the $\mathrm{h}^{2} / \mathrm{H}_{2}$ estimator indicates that there are no dominant genes for this trait.

Estimates of the number of genes or gene blocks with dominance, indicated by $\mathrm{h}^{2} / \mathrm{H}_{2}$ values, indicate the existence of at least five to seven genes or gene blocks in dominance for male flowering (MF), six or seven for female flowering (FF), eight or nine for grain yield (GY), one to four for crop moisture (HUM) and four or five for mass of one thousand seed (MTS). However, according to Cruz et al. (2012) this estimator underestimates the number of genes that exhibit little or no dominance.
Genotypic coefficients of determination in the broad sense were high (above 0.86) in all variables, while in the narrow sense they were moderate to low. When analyzing the values of the coefficient of determination in the narrow sense $\left(\mathrm{h}^{2} \mathrm{R}\right)$, it shows that it is possible to have different selection gains for each trait in different locations. For male and female flowering (MF and FF) and mass of one thousand seeds (MTS) the Palotina environment (PTNA) was more promising, with $\mathrm{h}^{2}{ }_{\mathrm{R}}$ value of 0.6272 . For harvest humidity (HUM) the best selection environments were Mariluz (MLZ) and Palotina (PTNA) with values of 0.60 and 0.59 respectively.

These results show the possibility of genetic gain and obtaining superior segregants for these traits, considering that, according to Cardoso et al. (2015), these magnitudes propose that the desirable alleles will be transmitted to the next generations with greater reliability. For grain yield (GY), a low coefficient of determination in the narrow sense is observed, showing that direct selection gains for this trait are more difficult. 
In the estimates of the genetic components, it is noticed a greater importance of the components related to the dominance effects $\left(\mathrm{H}_{1}\right.$, $\mathrm{H}_{2}$ and $\mathrm{h}^{2}$ ) than the components associated with the additive effects (D) for all studied variables (Table
6). Fact also evidenced by the negative value of D$\mathrm{H}_{1}$, showing predominance of dominance gene effects in the gene control of these variables and denoting potential gain through obtaining superior segregants.

Table 6. Estimation of the genetic components of the characters male and female flowering (FM and FF), grain yield (GY), crop humidity (HUM) and mass of one Thousand seeds (MMS), according to Hayman's methodology (1954).

\begin{tabular}{|c|c|c|c|c|c|c|c|c|}
\hline \multirow{2}{*}{ Trait } & \multirow{2}{*}{ Env. } & \multicolumn{7}{|c|}{ Component } \\
\hline & & $E$ & D & $\mathrm{H}_{1}$ & $\mathrm{H}_{2}$ & $h^{2}$ & $F$ & $\mathrm{D}-\mathrm{H}_{1}$ \\
\hline \multirow{4}{*}{ MF (days) } & MLZ & $0.391^{\text {ns }}$ & $15.730^{*}$ & $24.196^{*}$ & $17.980^{*}$ & $120.489^{*}$ & $13.889^{\star}$ & $-8.465^{\star}$ \\
\hline & SPI & $1.204^{*}$ & $16.442^{*}$ & $23.342^{*}$ & $15.328^{*}$ & $98.608^{*}$ & $16.518^{*}$ & $-6.900^{*}$ \\
\hline & PTNA & $0.158^{\text {ns }}$ & $4.708^{*}$ & $11.189^{\star}$ & $8.047^{*}$ & $44.212^{*}$ & $0.547^{\mathrm{ns}}$ & $-6.480^{*}$ \\
\hline & Average & $0.391^{\mathrm{ns}}$ & $9.952^{*}$ & $15.996^{*}$ & $11.693^{*}$ & $84.421^{*}$ & $6.713^{*}$ & $-6.044^{*}$ \\
\hline \multirow{4}{*}{ FF (days) } & MLZ & $0.374^{\mathrm{ns}}$ & $21.159^{*}$ & $29.745^{\star}$ & $21.495^{\star}$ & $152.337^{*}$ & $20.325^{\star}$ & $-8.585^{*}$ \\
\hline & SPI & $1.560^{*}$ & $15.309^{*}$ & $29.686^{*}$ & $21.845^{\star}$ & $146.907^{*}$ & $13.252^{*}$ & $-14.377^{*}$ \\
\hline & PTNA & $0.307^{\mathrm{ns}}$ & $8.217^{*}$ & $16.471^{*}$ & $12.566^{*}$ & $75.816^{*}$ & $1.287^{*}$ & $-8.253^{*}$ \\
\hline & Average & $0.019^{n s}$ & $12.491^{*}$ & $22.851^{*}$ & $18.006^{*}$ & $122.465^{*}$ & $7.412^{*}$ & $-10.370^{*}$ \\
\hline \multirow{4}{*}{ GY (kg ha-1) } & MLZ & $355632.21^{*}$ & $-240031.60^{*}$ & $13821029.3^{*}$ & $12748762.3^{*}$ & $108454735.4^{*}$ & $-433158.36^{*}$ & $-14061060.98^{*}$ \\
\hline & SPI & $163709.23^{*}$ & $156795.66^{*}$ & $5405319.57^{*}$ & $5236238.1^{*}$ & $42507785.2^{*}$ & $-147160.75^{\star}$ & $-5248523.90^{*}$ \\
\hline & PTNA & $193779.59^{*}$ & $70658.57^{*}$ & $9097133.01^{*}$ & $8231652.2^{*}$ & $71873685.8^{*}$ & $-65529.14^{*}$ & $-9026474.44^{*}$ \\
\hline & Average & $2.15^{*}$ & $107984.64^{*}$ & $8522996.57^{*}$ & $8075959.5^{*}$ & $71821952.2^{*}$ & $58974.19^{*}$ & $-8415011.93^{*}$ \\
\hline \multirow{4}{*}{ HUM (\%) } & MLZ & $0.185^{\mathrm{ns}}$ & $5.010^{*}$ & $8.403^{*}$ & $5.767^{*}$ & $20.434^{*}$ & $2.739^{*}$ & $-3.393^{*}$ \\
\hline & SPI & $0.874^{\text {ns }}$ & $11.823^{*}$ & $46.201^{*}$ & $36.458^{*}$ & $1.885^{\star}$ & $10.640^{*}$ & $-34.377^{*}$ \\
\hline & PTNA & $0.997^{\mathrm{ns}}$ & $6.011^{*}$ & $22.811^{*}$ & $16.306^{*}$ & $0.486^{\text {ns }}$ & $-2.286^{*}$ & $-16.800^{*}$ \\
\hline & Average & $0.199 \mathrm{~ns}$ & $3.419^{*}$ & $13.578^{*}$ & $10.217^{*}$ & $5.258^{*}$ & $-0.757^{\mathrm{ns}}$ & $-10.159^{*}$ \\
\hline \multirow{3}{*}{ MTS (g) } & MLZ & $0.333^{n s}$ & $1198.833^{*}$ & $5052.298^{*}$ & $3309.278^{*}$ & $15543.112^{*}$ & $2054.432^{*}$ & $-3853.464^{*}$ \\
\hline & PTNA & $0.333^{\text {ns }}$ & $2898.101^{*}$ & $5034.710^{*}$ & $3809.173^{*}$ & $16822.837^{*}$ & $2143.732^{*}$ & $-2136.609^{*}$ \\
\hline & Average & $0.333^{n s}$ & $1463.662^{*}$ & $4428.016^{*}$ & $3152.980^{*}$ & $16176.647^{\star}$ & $1816.610^{*}$ & $-1964.354^{*}$ \\
\hline
\end{tabular}

E: environmental variance component; $\mathrm{D}$ : variance component associated with additive effects; $\mathrm{H}_{1}$ and $\mathrm{H}_{2}$ : variance components associated with dominance deviations; $h^{2}$ : quadratic component determined by the mean difference between hybrids and parents; F: component associated with covariance between additive and non-additive effects; $\mathrm{D}-\mathrm{H}_{1}$ : component that expresses the difference between additive and dominant gene effects. ${ }^{*}$ and ${ }^{\text {ns: }}$ significant at $5 \%$ and not significant by t-test.

The highest concentration of dominant alleles for male flowering (MF) and female flowering (FF) are detected in the CD069, CD070, CD067, and CD072 lines (Figures 1 and 2), suggesting that the presence of dominant alleles provides greater precocity in male and female flowering (Table 8) and that it is possible to synthesize new populations with a higher degree of dominance thus reducing the time for flowering (Figures 1 and 2). The lineage with the highest concentration of recessive alleles is CD034, followed by the lineage CD008, which, due to its recessiveness, provides later flowering.

For grain yield (GY), we note a lineage positioning that indicates the presence of mainly recessive alleles for all lines for this trait (Figure
3), thus evidencing the low selection gain for grain yield in this group of lineages. The lines closest to the dominance regions of the graphs are the CD067 and CD038, and the line with the greatest presence of recessive alleles is the CD056. Analyzing the distribution of the strains in the graphs, it can be stated that hybrids and populations from the crossing of these lines will have low productive potential, since it is attributed by dominant alleles.

The line CD069 stands out with a higher number of dominant alleles for the harvest moisture variable (HUM) (Figure 4), which provide a higher rate of moisture loss and, consequently, greater precocity. For mass of one thousand seeds (MTS), we highlight the strains 
CD0056, CD038 and CD072 as those with the largest number of dominant alleles, evidencing the possibility of obtaining more dominant segregants or hybrids and possibly with the largest mass of one thousand seeds (MTS) (Figure 5).

\section{Conclusions}

Dominant alleles were found more frequently in parents, except for grain yield where there is a predominance of recessives. There is a predominance of dominance gene effects in the control of the studied variables with overdominance interaction between alleles.

At least five to seven gene blocks control male flowering, six or seven female flowering, eight or nine yield, one to three crop humidity, and four or five thousand seed masses in this parent group.

It is possible to have greater selection gains for male and female flowering and mass of one thousand seeds in Palotina environment. For crop humidity, higher gains are possible in Mariluz and Palotina environments.

The CD069 strain is recommended for use for breeding work because it has a larger number of genes in dominance for maturation providing earlier.

The CD038 strain is recommended for breeding work because it has a higher number of genes in dominance for grain yield and mass of one thousand seeds.

\section{References}

AMARAL JUNIOR, A.T. do.; CASALI, V.W.D.; CRUZ, C.D.; FINGER, F.L. 1999. Inferências genéticas na produção e qualidade de tomateiro sob cruzamento dialélico. Pesquisa Agropecuária Brasileira, 34(8):1407-1416.

CARDOSO, D.L.; VIVAS, M.; AMARAL JUNIOR, A.T. do.; PEREIRA, M.G. 2015. Análise dialélica de Hayman de características relacionadas à produção e a qualidade de frutos em mamoeiro. Bragantia, 74(4):394-399.

CRUZ, C.D.; REGAZZI, A.J.; CARNEIRO, P.C.S. 2012. Modelos biométricos aplicados ao melhoramento genético. 4 ed. v. 1. UFV, Viçosa, 514 p.

CRUZ, C.D. 2013. GENES - a software package for analysis in experimental statistics and quantitative genetics. Acta Scientiarum.Agronomy, 35(3):271-276.

FERREIRA, P.E. 1985. On Jinks-Hayman's analysis of half diallels. Revista Brasileira de Genética, $8(1): 149-155$.

FORNASIERI FILHO, D. 2007. Manual da cultura do milho. Funep, Jabuticabal, 576p.

FRISKE, É. 2016. Diversidade genética e mapeamento por associação em linhagens de milho para maturação de grãos. Marechal Cândido Rondon, PR, Dissertação (Mestrado em Agronomia) Universidade Estadual do Oeste do Paraná - Marechal Cândido Rondon.

GARDNER, C.O.; EBERHART, S.A. 1966. Analysis and interpretation of the variety cross diallel and related populations. Biometrics, 22(3):439-452.

GOMES, F.P.; GARCIA, C.H. 1991. Experimentos em látice: planejamento e análise por meio de "pacotes" estatísticos. Piracicaba: ESALQ/USP, 7(23):69. (Série Técnica). 
GRIFFING, B. 1956. Concept of general and specific combining ability in relation to diallel crossing systems. Australian Journal of Biological Sciences, 9(4): 463-493.

HAYMAN, B.I. 1954. The theory and analysis of diallel crosses. Genetics, 39(4):789-809.

LIMA, J.L.; SOUZA, J.C.; MACHADO, J.C.; RAMALHO, M.A.P. 2008. Controle genético da exigência térmica para o início do florescimento em milho. Bragantia, 67(1):127-131.

LOPES, U.V.; GALVÃO, J.D.; CRUZ, C.D. 1995. Inheritance of the flowering time in maize. Pesquisa Agropecuária Brasileira, 30(10):1267-1271.

MAKUMBI, D.; ALVARADO, G.; CROSSA, J.; BURGUEÑO, J. 2018. SASHAYDIALL: A SAS Program for Hayman's Diallel Analysis. Crop Science, 58(4):1605-1615.

MATOS FILHO, C.H.A.; GOMES, R.L.F.; ROCHA, M.M.; FREIRE FILHO, F.R.; LOPES, A.C. de A. 2009. Potencial produtivo de progênies de feijão-caupi com arquitetura ereta de planta. Ciência Rural, 39(2):348-354.

MORAES, M.L.T.; PATINO-VALERA, F.; MORI, E.S.; KAGEYAMA, P.Y. 1988. Aspectos práticos dos delineamentos em látice. Piracicaba: ESALQ/USP, 5(14):21. (Série Técnica).

ROHMAN, M.M.; OMY, S.H.; BEGUM, S.; RAHMAN, M.A.; HOSSAIN, M.G.; HOQUE, M.M.; AMIRUZZAMAN, M. 2019. Genetic action and potence ratio of maize in an $8 \times 8$ diallel cross growing under saline condition. Journal of Plant Breeding and Crop Science, 11(1):17-25.

SALEEM, M.; SHAZAD, K.; JAVID, M.; AHMED, A. 2002. Genetic analysis for various quantitative traits in maize (Zea mays L.) inbred lines. International Journal of Agriculture e Biology, 4(3):379382.

SCAPIM, C.A; CARVALHO, C.G.P; CRUZ, C.D. 1995. Uma proposta de classificação dos coeficientes de variação para a cultura do milho. Pesquisa Agropecuária Brasileira, 30(5):683-686.

SCHUELTER, A.R.; PEREIRA, G.M.; AMARAL JUNIOR, A.T.; CASALI, V.W.D.; SCAPIM, C.A.; BARROS, W.S.; FINGER, F.L. 2010. Genetic control of agronomically important traits of pepper fruits analyzed by Hayman's partial diallel cross scheme. Genetics and Molecular Research, 9(1):113-127.

SECRETARIA DE ESTADO DA AGRICULTURA E DO ABASTECIMENTO DO PARANÁ (SEAB). DEPARTAMENTO DE ECONOMIA RURAL (DERAL). 2017. Comparativo de área, produção e rendimento. Curitiba. Available at: http://www.agricultura.pr.gov.br/arquivos/File/deral/pss.xls.

SHER, H.; IQBAL, M.; KHAN, K.; YASIR, M.; RAHMAN, H. 2012. Genetic analysis of maturity and flowering characteristics in maize (Zea mays L.). Asian Pacific Journal of Tropical Biomedicine, 2(8):621-626.

SINGH, R.K.; CHAUDHARY, B.D. 1977. Biometrical methods in quantitative genetics analysis. Kalyani Publishers, Nova Delhi, Ludhiana, 288p. 
WATTOO, F.M.; SALEEM, M.; AHSAN, M.; SAIJAD, M.; ALI, W. 2009. Genetic analysis for yield potential and quality traits in maize (Zea mays L.). American-Eurasian Journal of Agriculture and Environment Scientiae, 6:723-729. 